\title{
Hindistan Jamia Millîa İslamia Üniversitesinde okutulan yabancılara Türkçe öğretimi Türkçe ders kitapları üzerine bir değerlendirme
}

\section{Muammer ŞEHİTOĞLU1}

\begin{abstract}
APA: Şehitoğlu, M. (2020). Hindistan Jamia Millîa İslamia Üniversitesinde okutulan yabancılara Türkçe öğretimi Türkçe ders kitapları üzerine bir değerlendirme. RumeliDE Dil ve Edebiyat Araşttrmalar Dergisi, (19), 106-127. DOI: 10.29000/rumelide.752153.
\end{abstract}

$\ddot{O} \mathbf{z}$

Araştırmanın amacı, Hindistan Jamia Millîa İslamia Üniversitesi Türk Dili ve Edebiyatı Bölümünde yürütülen yabancı dil olarak Türkçe öğretimi dersi kitaplarını dil bilgisi yaklaşımı ve dil yanlışlıkları açısından ele almak ve bunlara ilişkin çözüm önerileri sunmaktır. Araştırmada yöntem olarak, Türk Dili ve Edebiyatı Bölümünde okutulan Türkçe ders kitaplarının Türkçe öğretimindeki etkinliğini ve yeterliliğini değerlendirmek için nitel araştırma bağlamında doküman incelemesi ve içerik analizi tekniği kullanılmıştır. Araştırmaya ait veriler, 2017-2018 akademik eğitim-öğretim yılında Yunus Emre Enstitüsünün belirlemiş olduğu ilgili Türkçe seviyesindeki kitapların ünitelerinden oluşmaktadır. Veriler, okutulan ders kitaplarında yer alan metin, dil bilgisi ve temel beceriler bölümlerinin ünitelerinden elde edilmiştir. Verilerin analizinde ise, doküman incelemesi yöntemi ve içerik analizi tekniği birlikte kullanılmıştır. Araştırmadan elde edilen bulgulara göre; okutulan Türkçe ders kitaplarının özellikle metin seçimi ve metinlerin dil, yazım özellikleri bakımından bir kısım eksikliklere ve yanlışlıklara sahip olduğu tespit edilmiştir. Bu türden yanlışlık ve eksikliklere çözüm önerileri sunulmuştur.

Anahtar kelimeler: Yabancılara Türkçe öğretimi, Türkçe ders kitapları, dil bilgisi

\section{An assessment on Turkish language books for teaching Turkish to foreigners taught at Jamia Millîa İslamia University, India}

\begin{abstract}
The aim of the research is to deal with Turkish course books as a foreign language conducted in Jamia Millîa Islamia University Turkish Language and Literature Department in terms of grammar approach and language mistakes and to offer solutions for them. In the research, document analysis and content analysis technique was used in the context of qualitative research to evaluate the effectiveness and adequacy of Turkish textbooks taught in the Department of Turkish Language and Literature in teaching Turkish. The data of the research consist of the units of the books in Turkish level determined by Yunus Emre Enstitüsü in 2017-2018 academic year. The data were obtained from the units of the text, grammar and basic skills sections in the textbooks taught. In the analysis of the data, the document analysis method and the content analysis technique were used together. According to the findings obtained from the research; It was determined that Turkish textbooks taught have some deficiencies and inaccuracies especially in terms of text selection and language and spelling characteristics of the texts. Suggestions for solutions to such mistakes and deficiencies are presented.
\end{abstract}

$1 \quad$ Dr. Öğrencisi, Atatürk Üniversitesi, Eğitim Bilimleri Enstitüsü, Türkçe ve Sosyal Bilgiler ABD, Türkçe Eğitimi BD (Erzurum, Türkiye), mshtgl22@gmail.com, ORCID ID: 000o-0003-4471-3283 [Makale kaylt tarihi: 20.03.2020-kabul tarihi: 20.06.2020; DOI: 10.29000/rumelide.752153] 
Keywords: Teaching Turkish to foreigners, Turkish textbooks, grammar

\section{Giriş}

Yabancı dil olarak Türkçenin öğretimi, dünyadaki diğer doğal diller gibi Türkçenin de konuşur sayısını artırması ve Türk kültürünün doğru anlaşılması, yaygınlaşması ve öğrenilmesi adına çok değerlidir. Türkçenin ana dil olarak öğrenilmesi kadar önemli olan bu öğretim bugün Yunus Emre Enstitüsü, Maarif Vakfı gibi kurumlar aracılığıyla dünyanın değişik bölgelerinde sürdürülmektedir. Ayrıca, Türkiye'deki üniversitelerde de Türkçe Öğretim Merkezleri ve Dil Öğretim Merkezleri aracıllğıyla yabancı öğrencilere Türkçe öğretimi sunulmaktadır. Türkçenin ana dil olarak öğretiminde de gösterilen titizlik ve çaba yabancı dil olarak öğretilmesinde gösterilmekte ve devam edilmektedir. Dünya genelinde dil öğrenmeye olan merak ve ilgi gün geçtikçe artarken, gündelik yaşam ve çalışma ortamlarındaki farklı kültür ve dilleri konuşan insanlar için de yabancı bir dili öğrenmek iletişim ve kültürel etkileşim açısından değerlidir. Bu bağlamda, "Diller İçin Avrupa Ortak Başvuru Metni” de öğrenilecek hedef dil ile dil düzeylerinin tespit edilmesi ve tespit edilen düzeyler için belirlenen kazanımların ortaya konmasını sağlamıştır (Azizoğlu \& Uğur, 2015, s. 152). Türkçenin yabancı dil olarak öğretilmesinde bu ilkeler göz önünde bulundurulmuş ve Türkçenin ana dil olarak öğretilmesindeki ilkeler ve edinilen tecrübe de bu metin ışığındaki ilkelerle bütünleştirilerek Türkçenin yabancı dil olarak öğretilmesindeki ilkeler ve amaçlar belirlenmiş, öğretim programı ve ders kitapları hazırlanmıştır.

Yabancı dil olarak Türkçenin öğretiminde okutulan öğretim programı, ders kitapları, ilgili ders materyalleri, öğretimin doğru ve eksiksiz gerçekleştirilmesi için önemlidir. Dünyanın değişik bölgelerinde yabancı dil olarak Türkçe öğretimi yapan Yunus Emre Enstitüsü Yedi İklim Türkçe Ders Kitabı Seti hazırlayarak belirlenen seviyelerde Türkçe öğretimini gerçekleştirmektedir. Türkçe öğretimi için okutulan kitaplar, 'DİAOÇM'deki düzeyler ve yetenekler dikkate alınarak oluşturulmuştur. A1, A2, B1, B2, C1 ve C2 seviyelerinde Türkçe ders kitapları hazırlanmıştır. 72 saatlik kur süreci kullanılacak biçimde hazırlanan kitaplar, toplam sekiz üniteden oluşmaktadır. Ünitelerin her biri ise üç alt başlıktan meydana gelmektedir. Her ünitede, bölüm adları, edinilmesi gereken beceriler ve dil bilgisi konuları yer almaktadır. Ayrıca, cümle oluşturma yeteneğine yönelik sözcük alıştırmaları, Türk kültürünü doğru öğretmek amacıyla güncel olarak hazırlanmış "serbest okuma” parçaları ve de yine her ünitenin sonunda ölçme değerlendirme bölümü oluşturulmuştur. Millî Eğitim Bakanlığı tarafından 2004 yllında Türkçe dersinin öğretim programı olarak benimsenmiş olan yapılandırmacı yaklaşımı temel alan bu ders kitaplarında, bu yaklaşımın özelliklerine göre; öğrenci merkezli, birey temelli öğrenme ile birlikte çoklu zekâ kuramına göre bireysel farklılıkları önemseyen bir program anlayışı kabul edilmiştir. Aynı zamanda kitaplarda Türkçenin temel becerileri de yapılandırmacı okuma, konuşma, dinleme ve yazma başlıkları ile ifade edilmiş ve bunlara uygun alıştırmalar, uygulamalar hazırlanmıştır. Bu yaklaşımda, kuralların, ilkelerin ezberletilmesi yerine bunların metin parçaları ve ilgili uygulamalar ile öğrenene sezdirilmesi amaçlanmıştır (Güneş, 2009; s. 40; Başar, 2016; ss. 56-57). Yapılandırmacı yaklaşımı savunan J. Piaget, Vygotksy ve Bruner tarafından, bu öğrenme yaklaşımının öğrenen bireyin aktif tavrıyla öğrenmeyi zihninde yapılandırarak gerçekleştirdiği dile getirilmiştir (Güneş, 2013; s. 82). Bu bakımdan, hem dil bilgisinin öğretimi hem de becerilerin edinilmesi ile ilgili yeni bir yaklaşım sunulmuştur. Türkçenin yabancı dil olarak öğretilmesinde de bu yaklaşım benimsenmiştir.

Öte yandan yabancı dil olarak Türkçenin öğretiminde dil bilgisi konuları da diğer konular gibi önemlidir. Yapılandırmacı yaklaşıma göre hazırlanan Türkçe ders kitaplarında da bu yaklaşım 
An assessment on Turkish language books for teaching Turkish to foreigners taught at Jamia Millîa İslamia University, India / M. Şehitoğlu (pp. 106-127)

doğrultusunda üniteler belirlenmiş ve konular boyutunda sınıflandırılmıştır. Türkçe ders kitaplarındaki dil bilgisine ait konular, ünitelerin metin parçalarının içeriğine göre basitten-karmaşığa, kolaydan-zora doğru ilkelerince düzenlenmiştir. Temel becerilere ait uygulamalar ve alıştırmalar ise, ünitelerin sonunda yapılacak etkinliklere bağlı olarak çeşitlendirilmiştir. Yaklaşımın temelinde yer alan bilginin zihinde yapılandırılarak öğrenilmesi, dil bilgisi konularının da öğrenilmesinde esas görülmüştür. Yaklaşım, analiz, sentez ve değerlendirme gibi üst bilişsel becerilerin etkin kullanılmasını öğrenme sürecinde önemli görmekte, bilgiyi üst üste yığmak değil, bilgiye kendi yorumunu katarak onu yeniden kurmak hedeflenmektedir (akt., Başar, 2016, s. 57). Yaklaşımın, öğrenme sürecinin öğrenen merkezli olarak öğrenenin zihninde yapılandırarak öğrendiği bir sürece dönüştüğü ve bunun da tüm yaşamındaki öğrenmelerin yaklaşımı olarak benimsendiği açıktır. Yabancı dil olarak Türkçenin öğretilmesinde ise, bu durum dil bilgisi için geçerlidir. Çünkü yazma, okuma, dinleme ve konuşma becerilerini doğrudan etkileyen konudur. Öğrenenin tüm yaşamı boyunca öğrendiği dilin anlamlı ve görevli ögelerini işlevsel kullanması bu sayede gerçekleşecektir. Hindistan Jamia Millîa İslamia Üniversitesinde de Türk Dili ve Edebiyatı Bölümünde Türkçe öğretimi için belirlenen seviyelere uygun ders kitapları Yunus Emre Enstitüsü tarafından hazırlanmış ve öğrenen ile öğreticilerin kullanımına sunulmuştur. Çalışmanın gerçekleştirildiği Hindistan'da eğitim-öğretim faaliyetinde bulunan üniversite ile ilgili ise, şu bilgiler mevcuttur:

29 Ekim 1920 tarihinde, Aligarh Koleji Müslümanlarının National Muslim University (Câmiye Milliye İslâmiye) adı ile kurduğu Jamia Millîa İslamia Üniversitesi, Hindistan'ın önemli üniversitelerinden biridir. Kuruluşunda M. Gandi'nin de desteği olan üniversite, 1925 yllında başkent Yeni Delhi'ye taşınmıştır. Ünlü ekonomist Zâkir Hüseyin başta olmak üzere eğitimci olarak Âbid Hüseyin ve matbaacı olan Muhammed Mucib gibi önde gelen insanların da desteğiyle 1926 yllında akademik olarak bilinir konuma gelmiştir. Halide Edip Adıvar ve Hüseyin Rauf Orbay'in da konferanslar düzenleyip maddi destek verdiği üniversite 1936 yılında Okla Bölgesi’ne taşınmış ve 1939 yllında ise, cemiyette resmî statü elde etmiştir. 1962 yllındaki iç karışıklıklarda birçok sorun yaşayan üniversite yurt dışından birçok devlet başkanı ve kralın desteğiyle eğitim öğretime devam etmiştir. 1988 yllında, ülkedeki yasalar gereğince varlığı kabul edilen bir eğitim kurumu olmuştur. Yıllar içinde akademik olarak birçok fakülte kurulan üniversitede bugün tıp, hukuk, sosyal ve insani bilimler, mühendislik, doğa bilimleri, diş hekimliği alanları ile ilgili bölümler ve araştırma merkezleri bulunmaktadır (TDV İslam Ansiklopedisi Ek-1, 2016, ss. 244-246; Bilkan, 2011, ss. 33-35).

Üniversite bünyesinde yer alan İnsani Bilimler ve Diller (Faculty of Humanities and Languages) Fakültesine bağlı olarak eğitim ve öğretime devam eden Türk Dili ve Edebiyatı Bölümü 2017-2018 akademik eğitim-öğretim yllında yaklaşı 130 öğrenciye sahiptir. Lisans eğitimi 3 yll süren bölümde ayrıca özel olarak sertifika, diploma ve ileri diploma seviyelerinde Türkçe eğitimi-öğretimi de verilmektedir. Öğrencilerin genel olarak Müslümanlardan oluştuğu bölümde ayrıca Hindu, Budist ve Hristiyan öğrenciler de mevcuttur.

Çalışmada, Türk Dili ve Edebiyatı Bölümünde yabancılara Türkçe öğretimi için okutulan ders kitapları ile ilgili genel tespitler ile birlikte ders kitaplarının dil bilgisi ve okuma metinleri bölümlerindeki eksiklikler, yanlışlıklar tespit edilmiş ve bunların çözümüne yönelik öneriler dikkatlere sunulmuştur.

\section{Araştırmanın amacı}


Araştırma, Hindistan Jamia Millîa İslamia Üniversitesi Türk Dili ve Edebiyatı Bölümündeki yabancılara Türkçenin öğretimi ile ilgili okutulan ders kitaplarındaki dil bilgisi yaklaşımı ve dil yanlışlıklarını ele almak ve onlara ilişkin çözüm önerileri sunmayı amaçlamaktadır.

Araştırmaya ait alt problemler ise şöyledir:

Türkçe ders kitaplarının genel özellikleri nelerdir?

Okutulan ders kitaplarındaki dil bilgisi konularının dağılımı ve ünite sınıflandırılması öğretim bakımından uygun mudur?

Türkçe ders kitaplarındaki okuma ve alıştırma metinlerinde dil yanlışları var mıdır?

Türkçe ders kitaplarındaki okuma ve alıştırma metinlerindeki dil yanlışlıklarının nedenleri nelerdir ve bu nedenler hangi konular üzerinde daha yoğundur?

Okuma ve alıştırma metinlerindeki yanlışlıklar hangi temel dil seviyesinde daha yoğundur?

\section{Araştırmanın yöntemi}

Araştırma, Hindistan Jamia Millîa İslamia Üniversitesi Türk Dili ve Edebiyatı Bölümünde okutulan Türkçe ders kitaplarındaki dil bilgisi yaklaşımının ve temel beceriler seviyesindeki okuma / alıştırma metinlerindeki dil yanlışlıklarının incelenmesine yönelik nitel bir araştırmadır. Araştırmada, doküman incelemesi tekniği kullanılmıştır.

Doküman incelemesi, araştırma kapsamında incelenen konuyla ilgili olgu ve olaylar hakkında bilgi içeren yazılı belgelerin analiz edilmesiyle veri sağlanmasıdır. İnceleme, araştırma yapılan alanla ilgili belge inceleme yoluyla gerçekleştirilir. Dokümanların kullanımı ise, araştırma konusu alanına göre değişiklik göstermektedir ve inceleme yapılırken bu durum göz önünde bulundurulmalıdır (Şimşek \& Yıldırım, 2008, s. 188). Araştırma, bu bakımdan tek bir analiz ve veri toplama yöntemi ile birlikte tek bir araştırma değerler dizisine ait incelemeyi kapsamaktadır.

\section{Verilerin toplanması}

Veriler, 2017-2018 akademik eğitim-öğretim yllında Yunus Emre Enstitüsünün belirlemiş olduğu ilgili Türkçe seviyesindeki kitapların ünitelerinden oluşmaktadır. Veriler, okutulan ders kitaplarında yer alan metin, dil bilgisi ve temel beceriler bölümlerinin ünitelerinden elde edilmiştir.

\section{Verilerin analizi ve yorumlanması}

Araştırmada, nitel araştırma yöntemine ait içerik analizi tekniği kullanılmıştır. İçerik analizinde amacın elde edilen verileri betimleyecek kavram ve ilişkilere ulaşmak olduğu belirtilirken analizde yapılan temel işlem ise, birbirine benzeyen verileri belirlenmiş temalar ve kavramlar çerçevesinde bir araya getirmek olarak açıklanmaktadır (Şimşek \& Yıldırım 2012). Bu bağlamda okutulan ders kitaplarından elde edilen veriler Türkçenin öğretimi ile ilgili çağdaş öğretim yaklaşımları (yaşam boyu öğrenme, bütüncül öğrenme $v b$.) açısından ele alınmış bu açılardan elde edilen eksiklik ve yanlışlıklar tespit edilmiştir. Tespit edilen eksiklik ve yanlışlıklar metin, dil bilgisi ve temel beceriler açısından 
An assessment on Turkish language books for teaching Turkish to foreigners taught at Jamia Millîa İslamia University, India / M. Şehitoğlu (pp. 106-127)

kategorilere ayrılarak incelenmiştir. İncelenen her kategorideki nitel veriler anlamlı biçimde yorumlanmaya çalışılmıştır.

\section{Geçerlik/ güvenirlik}

Okutulan Türkçe ders kitaplarının kapsam geçerliği Yunus Emre Enstitüsünün Türkçe eğitimi uzmanları tarafından sağlanmış ve onaylanmıştır. Ayrıca, çalışma için araştırmacının bağlı bulunduğu Türkçe Eğitimi Bilim Dalındaki Türkçe eğitimi uzmanlarından ilgili kategoriler için görüş ve destek alınmıştır.

\section{Araştırmacinın rolü}

Araştırmacı, çalışmada elde edilen verilerin geçerlik düzeyi ve güvenirliği için somut çaba göstermiştir. İlgili üniversitedeki öğretimi gerçekleştiren araştırmacı doğrudan sahadan edindiği geri dönüşleri çalışma için temel alarak elde edilen bulguları doğru anlamlandırmaya ve yorumlamaya çalışmıştır.

\section{Bulgu ve yorumlar}

\section{Türkçe öğretimi için kullanılan kitap ile ilgili genel tespitler}

Hindistan'ın iklim koşulları, üniversitenin imkân ve kabiliyetleri ve de öğrencilerin beklenti ve amaçları bölümde sunulan Türkçe öğretimi için olumsuz durumlar meydan getirmiştir. Özellikle Fars Dili ve Edebiyatı Bölümünde sunulan öğretim yöntem ve tekniklerinin klasik öğretim yöntemlerine ve tekniklerine dayanıyor olması da bu bölüme bağlı olan Türk Dili ve Edebiyatı Bölümünü olumsuz etkilemiştir. Öyle ki Türkçe ders kitaplarındaki etkinliklerin çağdaş öğretim yöntemlerine göre hazırlanmış olması klasik öğretim yöntemleri ile öğrenmeye alışmış öğrenciler için zorluklar oluşturmuştur. Özellikle de Türkçenin temel becerileri için yapılması gereken etkinliklerin bilgisayar, yansıtım gibi teknolojik ders materyalleri ile etkili işlenmesi gereken durumlarda öğrencilerin bu hazırbulunuşluk ve güdülenme eksikliği, sınıfların fiziksel yetersizliği ile birlikte Türkçe öğretimini olumsuz etkilemiştir.

Öte yandan, bölümdeki öğrencilerin Farsçayı Ana dili seviyesinde veya ona yakın seviyede biliyor olması ve Delhi'de yaşayan Müslümanların çoğunlukla gündelik yaşamda iletişimsel dil olarak kullandıkları Urducanın Farsçaya yakın dil özellikleri göstermesi de bu durumda etkilidir. Ayrıca tecrübeli öğretim görevlilerinin sayısının fazla olması ve Urduca ve Farsçayı iyi bilmeleri Farsçanın öğretimi için çok fazla yöntem tekniğe başvurulmamasına neden olmuştur. Böylelikle de modern dil öğretimi için kullanılan yöntem ve teknikler kolaycıllk, teknolojik cihazları kullanma yeteneğinin bulunmaması gibi nedenlerle tercih edilmemiştir. Türkçe öğretimi de yaşanan bu durum ve süreçten olumsuz etkilenmiştir. Ancak görevli Türk öğretim görevlileri tarafından bu olumsuz etki durumu da koordinatörlük ile doğru iletişim sayesinde en aza indirilmiştir. 

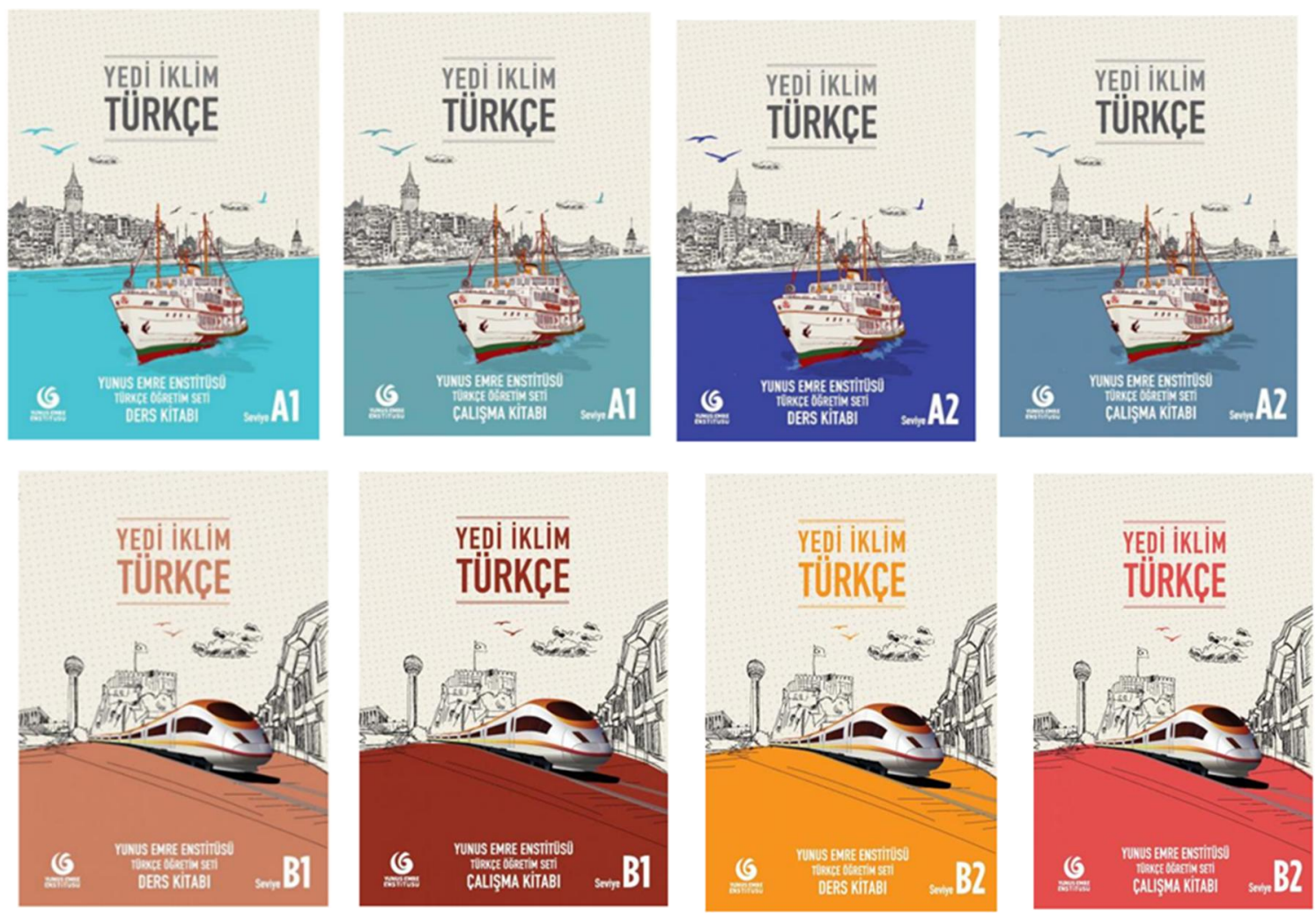

Resim.1 Lisans seviyesinde Türkçe ders kitapları.

\section{Okutulan Türkçe ders kitaplarındaki dil bilgisi konularının dağılımı ve sınıflandırılması ile ilgili tespitler}

Kitaplarda tespit edilen dil bilgisi ünitelerine dair şu değişiklikler gerçekleştirilebilir:

A1 düzeyi Türkçe ders kitabının ilk ünitesine bulunma durum eki ve işaret sıfatları konusu ile başlanmıştır. İkinci ünitede ise, diğer durum ekleri konusu ele alınmıştır. İlk iki ünitedeki bu tercihler yapılandırmacı yaklaşıma göre hazırlanan dil bilgisi öğretimindeki sezdirme yöntemiyle öğretimi amaçlamaktadır. Ancak ilk ünitede ilgili okuma metninde sadece bulunma durum eklerini içeren cümleler yer almıştır. Bunun yerine bulunma durumunu da kolaylıkla keşfedeceği ayrılma durum eklerini de içeren bir okuma metni tercih edilebilirdi. Çünkü sezdirme yönteminde, öğrenciler, bilgileri deneysel tipteki etkinliklerle keşfedebilecekleri, zihinde düşünme ve sorgulama becerisi ile tümevarım modeliyle birleştirebilecekleri için zihinlerinde daha kolay yapılandırmalarının mümkün olacağı uzmanlar tarafından dile getirilmiştir (Güneş, 2013). Ayrıca bulunma ve ayrılma durum ekleri karşılaş̧ırmalı bir biçimde metin aracılı̆̆ıyla sezdirilirse öğrenme süreci daha kolay olabilecektir. 
An assessment on Turkish language books for teaching Turkish to foreigners taught at Jamia Millîa İslamia University, India / M. Şehitoğlu (pp. 106-127)

Resim 2. A1 düzeyi Türkçe ders kitabındaki ünite sıralaması

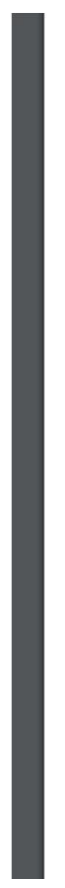

\begin{tabular}{|c|c|c|c|}
\hline \multirow{4}{*}{$\begin{array}{c}1 \\
\text { TANIŞMA }\end{array}$} & Tanışma & $9-32$ & Dil Bilgisi \\
\hline & A) Merhaba & 10 & $\begin{array}{l}\text { - bu, şu, o, burası, şurası, } \\
\text { orası }\end{array}$ \\
\hline & B) Nerelisiniz? & 17 & $\begin{array}{l}\text { - ml? / değil } \\
\text { - var / yok }\end{array}$ \\
\hline & C) Karşılaşma - Selamlaşma & 25 & $\begin{array}{l}\text { - Bulunma Hâli Eki } \\
\text { - Sayilar } \\
\text { - Çokluk Eki }\end{array}$ \\
\hline
\end{tabular}

\begin{tabular}{|c|c|c|c|}
\hline \multirow{4}{*}{ Ailemiz } & Ailemiz & $33-54$ & Dil Bilgisi \\
\hline & A) Ailem ve Ben & 34 & \multirow{3}{*}{$\begin{array}{l}\text { - Ayrilma Hâli Eki } \\
\text { - Belirtme Hâli Eki } \\
\text { - Bulunma Hâli Eki } \\
\text { - Yönelme Hâli Eki } \\
\text { - - DAn önce, -DAn sonra } \\
\text { - Emir } \\
\text { - Şahıs Zamirleri } \\
\text { - Șimdiki Zaman }\end{array}$} \\
\hline & B) Evim & 39 & \\
\hline & C) Adresim & 49 & \\
\hline
\end{tabular}

\begin{tabular}{|c|c|c|c|}
\hline \multirow{4}{*}{$\begin{array}{c}\text { GÜNLÜK } \\
\text { HAYAT }\end{array}$} & Günlïk Hayat & $55-76$ & Dil Bilgisi \\
\hline & A) Saat Kaçta? & 56 & \multirow{3}{*}{$\begin{array}{l}\text { - Belirti Geçniş Zaman } \\
\text { - Zaman Zarflar } \\
\text { - - -le -y/A } \\
\text { - DAnönce, -DAn sonra }\end{array}$} \\
\hline & B) Ne Kadar? Kaç Lira? & 64 & \\
\hline & C) Nerede? Ne Zaman? & 70 & \\
\hline
\end{tabular}

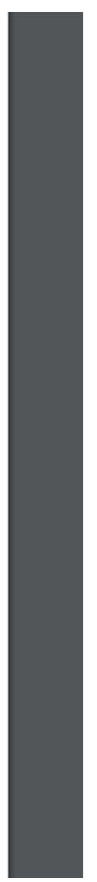

A2 düzeyi Türkçe ders kitabında ilk ünitedeki örnek metinde gelecek, geçmiş ve şimdiki zamanı vurgulayan cümleler yer alırken dil bilgisi konusu olarak belirsiz geçmiş zaman ele alınmıştır. İkinci ünitede, pekiştirme edatları konusu yer almıştır. Üçüncü ünitede ise, tekrar geniş zaman konusu yer almaktadır. Okuma metni olarak verilen örnek metinde üçüncü ünitede yer alan geniş zaman konusu da yer alabilirdi. Veya iki ayrı küçük örnek metin seçilerek ve bol örnek kullanılarak bu türden zaman karşılaştırılması yapılıp hem zamanlar ile ilgili biçim birim örnekleri hem de anlam ögeleri birlikte ele alınarak analiz yöntemiyle sezdirilmesi amaçlanabilirdi. Çünkü dil bilgisi öğretiminde metinler dilin etkin öğrenilmesinde önemli bir kaynak olmuştur. Dil bilgisi öğretiminde bu açıdan metinler önemlidir. Konuyla ilgili olarak, Thornbury, dil bilgisinin en iyi bağlam içinde öğretileceği ve pratik edileceğini belirterek metinlerin bütün halinde bağlam olarak kullanılması gerektiğini dile getirirken; Gower, Phillips ve Walter da, dilin keşfi için metnin doğal bir bağlam olduğunu ve dil ögeleri ile dil yapılarının analizi ve pratiğinin yapılmasını sağlayan bir havuz olarak açıklamışlardır (akt., Dilidüzgün \& Yılmaz, 2019, s. 219). Bu bağlamda düşünüldüğünde dil bilgisi öğretiminde metin bağlamındaki dil konularının ve yapılarının sahip oldukları iletişim işlevi de öğrenci / öğrenen için değerli görülmüş ve onların özümsenerek öğrenilecek ortamın hazırlanması da öğreten için önemli bir sorumluluk olarak görülmüştür. Öte yandan, yapılandırmacı yaklaşımda da vurgulanan; değişimden kurala, özelden genele ilkeleri doğrultusunda zaman konusu zihinde yeni bir senteze ulaşlarak daha kolay anlaşlabilecektir (Güneş, 2013). Ayrıca süreçte öğrenen merkezli öğrenme temel alınarak öğrencilerin oluşturacağı metinler aracılı̆̆ıyla da aktif kazanım sağlanabilecek etkinlikler de yapılabilir. Böylece yazma ve okuma becerileri birlikte kazanılmış ve geliştirilmiş olabilecektir. 
Resim 3. A2 düzeyi Türkçe ders kitabı ünite sıralaması

\begin{tabular}{|c|c|c|c|}
\hline \multirow{4}{*}{$\begin{array}{l}\text { ZAMAN } \\
\text { MEKÂN }\end{array}$} & Zaman - Mekân & $9-28$ & Dil Bilgisi \\
\hline & A) Geçmiş, Şimdi, Gelecek & 10 & \multirow{3}{*}{$\begin{array}{l}\text { - Belirsiz Geçmiş Zaman } \\
\text { (-mlș) } \\
\text { - -DAn önce } \\
\text { - -DAn sonra } \\
\text { - -mAdAn önce } \\
\text { - - DlktAn sonra }\end{array}$} \\
\hline & B) Zaman Planlaması & 17 & \\
\hline & C) Farklı Şehirler, Farklı Hayatlar & 21 & \\
\hline
\end{tabular}

\begin{tabular}{|c|c|c|c|}
\hline \multirow{4}{*}{$\begin{array}{l}\text { SAĞLIKLI } \\
\text { YAŞAM }\end{array}$} & Sağlıklı Yaşam & $29-48$ & Dil Bilgisi \\
\hline & A) Her Şeyin Başı Sağlık & 30 & \multirow{3}{*}{$\begin{array}{l}\text { - Pekisstirme } \\
\text { - gibi, kadar }\end{array}$} \\
\hline & B) Dünyamız Kirleniyor & 39 & \\
\hline & C) Trafik Canavarı & 43 & \\
\hline
\end{tabular}

\begin{tabular}{|c|c|c|c|}
\hline \multirow{4}{*}{$\begin{array}{c}3 \\
\text { SOSYAL } \\
\text { ETKINLIKLER }\end{array}$} & Sosval Etkinlikler & $49-70$ & Dil Bilgisi \\
\hline & A) Okumayı Seviyorum & 50 & \multirow{3}{*}{$\begin{array}{l}\text { - Geniş zaman (-Ir / -Ar / -r) } \\
\text { - - CA, -A göre } \\
\text { - bu yüzden / bu sebeple } \\
\text { - belki ... belki } \\
\text { - hem ... hem } \\
\text { - ne ... ne } \\
\text { - ya ... ya }\end{array}$} \\
\hline & B) Hangi Filme Gidelim? & 56 & \\
\hline & C) Spor Yap, Zinde Kal & 62 & \\
\hline
\end{tabular}

B1 düzeyi Türkçe kitabında, birinci ünitede zarf-fiil konusu belirlenmiş ve ilk ünitede başka bir konu seçilmiştir. Bir önceki aşama kitabı olan A2 düzeyi ders kitabında son ünitede fiilimsi konusunun yer aldığı düşünüldüğünde bir üst aşama olan B1 düzeyi ders kitabında ise, ilk ünitenin sıfat-fiil ve zarf fiil konularını içermesi daha doğru olacaktır. Çünkü yapılandırmacı yaklaşımın temelindeki kolaydan zora, basitten karmaşığa ilkeleri uyarınca düzenlenmesi öğrenme sürecini olumlu etkileyecektir. Ayrıca yine en az iki örnek metin ve okuma metinleri ile bu iki konuyu sezdirmeye yönelik içerikler hazırlanabilirdi. 
An assessment on Turkish language books for teaching Turkish to foreigners taught at Jamia Millîa İslamia University, India / M. Şehitoğlu (pp. 106-127)

Resim 4. B1 düzeyi Türkçe ders kitabı ünite sıralaması

\begin{tabular}{|c|c|c|c|}
\hline & Haberin Var Mı? & $9-26$ & Dil Bilgisi \\
\hline \multirow{3}{*}{$\begin{array}{l}\text { HABERIN } \\
\text { VAR MI? }\end{array}$} & A) Fisıltı Haberleri & 10 & \multirow{3}{*}{$\begin{array}{l}\text { - Zarf fiil -(y)ken } \\
\text { - Șimdiki Zamanın Hikâyesi } \\
\text {-(I)yordu }\end{array}$} \\
\hline & B) Son Dakika & 16 & \\
\hline & C) Sosyal Medya & 21 & \\
\hline & Yorumlar ve Görüşler & $27-46$ & Dil Bilgisi \\
\hline & A) Söyleşi & 28 & \\
\hline VE GÖP & B) iş Görüşmesi & 33 & - ișteșlik - Ișteş Çatı -(1)ș \\
\hline & C) Zevkler ve Renkler Tartışılmaz & 41 & \\
\hline & Eğitim & $47-68$ & Dil Bilgisi \\
\hline ЕĞітім & A) Eğitim Şart! & 48 & - Dilek Kipi -sA \\
\hline & B) Bir Lisan, Bir İnsan & 57 & $\begin{array}{l}\text { - Dilek Kipinin Hikâyesi } \\
\text {-sAydl }\end{array}$ \\
\hline & C) Kitap Kurdu & 62 & - Șart Kipi -(y)sA \\
\hline
\end{tabular}

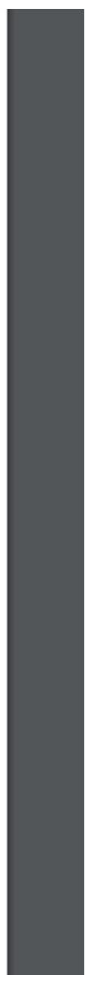

Ünitelerde dil bilgisi konularının sınıflandırılma biçimi yapılandırmacı yaklaşımın ilkelerine göre düzenlenmiştir. Bu ilkelerde en önemli unsur, öğrenenin zihninde öğrenme süreci boyunca yapbozun parçaları gibi öğrendiklerini kendi kurduğu bağlarla bütün olarak bir araya getirmesinin sağlanması ve öğrenmeye açı, bilinçli ve etkin bir şekilde dil becerisi elde etmesidir (Güneş, 2011). Bu nedenle kitaplarda yer alan dil bilgisi konularının metinlerden hareketle birbirini tamamlayacak, öğrenenin zihninde yakın zaman süreci boyunca en hızlı biçimde keşfedeceği, öğreneceği ve beceriye dönüştüreceği bir sıralama ve sınıflandırma yapılması gerektiği ortadadır. Öyle ki bunun için metin kaynaklı ve daha çok etkinliğe dayalı bir etkin öğrenme süreci hazırlanmalı. Böylelikle öğrenenin zevk aldığı̆, öğrenmek için istek duyduğu ve kendi öğrenme yöntemini keşfettiği öğrenme süreci oluşacaktır.

\section{Okutulan Türkçe ders kitaplarında yer alan okuma ve alıştırma metinlerine yönelik tespitler}

\section{Anlatım bozukluğu ve dil yanlışlıklarına yönelik tespitler}

$\mathrm{Bu}$ bölümde elde edilen bulgular anlatım bozukluğu ile birlikte yazım yanlışlarını ve noktalama işaretlerini de içermektedir. Bu sayede elde edilen nitel verilerin metin bağlamında bütüncül olarak anlamlandırılmasının ve yorumlanmasının kolaylaşması hedeflenmiştir.

A1 Türkçe Ders Kitabı: Ders kitabında bir eksiklik ve yanlışlık tespit edilememiştir.

\section{A2 Türkçe Ders Kitabı:}

Ders kitabının ilk ünitesinde yer alan okuma parçasında 
“...Önce kara kalem çalıştım. Sonra yağlı boya ve pastel boya resimler yapmaya çalıştım.” (s.12) cümlesi bozuktur.

Doğru cümle;

...Önce kara kalem resimler yapmaya çalıştım. Sonra yağlı boya ve pastel boya resimler yapmaya çalıştım.” șeklinde olmalıydı. Cümlede söz grubu eksikliğinden kaynaklanan anlatım bozukluğu vardır. Cünkü "kara kalem" de yağlı boya ve pastel boya ile yapılan bir resim türünü nitelemektedir. Dolayısıyla tamlananı eksik olan sıfat tamlaması nedeniyle anlatım bozulmuştur.

İlk ünitedeki diğer örnek de yine bir okuma parçasında yer alan resim sergisi konulu diyalog cümlesine aittir. İki kişi arasında resim sergisinde resimlerini sergileyen ressamın İstanbul'a gelişi ile ilgili sorucevap cümlesi yer almaktadır. Cümlede özne eksikliğinden kaynaklanan anlatım bozukluğu vardır. Cümle şöyledir:

"Murat: İstanbul'a ne zaman ve niçin gelmiştir?

Yaren: İki yll önce. Üniversitede okumak için gelmiş. (s.13).

\section{Doğrusu;}

Murat: İstanbul'a ne zaman ve niçin gelmiştir?

Yaren: Ressam, İstanbul'a iki yll önce üniversite okumak için gelmiş.”

Diğer bir örnek “Üç Önemli İnsan” adlı okuma parçasında yer almaktadır. Parçada, Kıraç adlı sanatçı ile ilgili bilgi verilirken şöyle bir cümle kullanılmıştır:

“...1999 yll mayıs ayında ilk albümünü hazırladı.” (s.14).

\section{Doğrusu;}

“...1999 yllının Mayıs ayında ilk albümünü hazırladı.” biçiminde olmalıydı. Cümlede, ilgi ekinin eksikliğinden kaynaklanan bir anlatım bozukluğu vardır. Ayrıca, "mayıs" sözcüğü 1999 yılını belirttiğgi için ay adı olarak büyük yazılmalıdır.

Başka örnek, "Tatlı Telaş" adlı okuma parçasında geçen diyalog cümlesinde yer almaktadır. Cümlede, ressamın bulunması ile ilgili bilgi verilmek istenmiştir. Cümle şöyledir:

Kemal Bey: Ressam bulunmuş mu?

Yaren: Hayır baba, henüz bulunmamış. (s.18).

\section{Doğrusu;}

Kemal Bey: Ressam bulunabilmiş mi?

Yaren: Hayır baba. Henüz bulunamamış.” şeklinde olmalıydı.

Çünkü soruya iki cevap verilmiştir. İlk cevap doğrudan, ikinci cevap ise açlklama türündendir. Dolayısıyla bu iki cevap cümlesi arasında nokta bulunması doğru olacaktır. Ayrıca, "bulunmuş mu" sorusuna arama eyleminin devam ettiğini belirtmek için "Henüz bulunamamış" şeklinde cevap verilmesi daha doğru olacaktır. Çünkü eylemden eylem yapan " $\mathrm{A}$ " yapım eki "yeterlilik" kipindedir. $\mathrm{Bu}$ bağlamda bu metin parçasının altıncı ünitedeki dil bilgisi konusuna yönelik işlenmesi ya da bu ünitenin konusuna uygun başka bir metin seçimi yapılması daha doğru olacaktır. 
An assessment on Turkish language books for teaching Turkish to foreigners taught at Jamia Millîa İslamia University, India / M. Şehitoğlu (pp. 106-127)

Yine diğer bir örnek, “Ağrı Dağı Efsanesi (İki Bacı)” adlı okuma metninde yer almaktadır. Metinde yer alan cümle şöyledir:

“...Büyük kardeş odunların hepsini küçük kardeşinin sırtına yüklemişs ve yola çımışlar.” (s.19). İki cümleden oluşan bu bölümün ikinci cümlesindeki özne ve durum tümleci eksikliği anlatım bozukluğuna neden olmuştur.

\section{Doğrusu;}

“...Büyük kardeş odunların hepsini küçük kardeşinin sırtına yüklemiş ve onlar beraber yola çımışlar.” şeklinde olmalıydı.

Başka bir örnek, iş başvurusu konusunu içeren "Müjde" adlı okuma metninde yer almaktadır. Metindeki cümle şöyledir:

"Hatice Hanım: Oğlum, bize niçin söylemedin?

Ahmet: Sürpriz yapmak istedim.” (s. 22). İkinci cümledeki seslenme tümleci ve yönelme tümleci eksikliği nedeniyle anlatım bozukluğu oluşmuş̧tur.

Doğrusu;

"Hatice Hanım: Oğlum, bize niçin söylemedin?

Ahmet: Anne, size sürpriz yapmak istedim.” biçiminde olmalıydı.

Yine aynı metin parçasında geçen diğer bir örnek cümle ise şöyledir:

"Hatice Hanım: Gözün aydın, çok sevindim. Ne zaman başlyorsun?

Ahmet: On beş gün içinde. Hazırlıklarımı tamamladıktan sonra gideceğim.” (s.22). Ahmet’in cevabını içeren cümledeki nokta işareti gereksizdir ve anlamı eksiltmiştir.

\section{Doğrusu;}

"Hatice Hanım: Gözün aydın, çok sevindim. Ne zaman başlyorsun?

Ahmet: Hazırlıklarımı tamamladıktan sonra gideceğim. On beş gün içinde başlayacağım.” şeklinde olmalıdı.

"Alerjik Nezle" adlı okuma parçasında yer alan örnekler şöyledir:

“...Ancak bazı insanlar da baharla birlikte hapşırı, öksürük, burun akıntısı, kaşıntı ve gözlerde kızarıklık şikâyetleri başlıyor.” (s.33) Cümlesinde -da biçim birimi bulunma durumunu karşılamış olmasına rağmen ayrı yazılarak yazı yanlışına neden olmuş ve cümlenin anlamını da bozmuştur.

Doğrusu;

“...Ancak bazı insanlarda baharla birlikte hapşırık, öksürük, burun akıntısı, kaşıntı ve gözlerde kızarıklık şikâyetleri başlıyor." biçiminde olmalıydı.

Yine aynı metindeki diğer örnek ise şöyledir:

“... Bu tedavi alerji şurubu ve hapları, göz damlaları ve burun spreyleri ile mümkün.” Cümlesinde dür bildirme eki eksikliği nedeniyle de anlatım bozulmuştur.

Doğrusu; 
“... Bu tedavi alerji şurubu ve hapları, göz damlaları ve burun spreyleri ile mümkündür.” şeklinde olmalıydı.

"İhtiyarlıktandır” adlı okuma parçasındaki örnekler;

“İhtiyar: Her şeyi unutuyorum doktor bey, hafızam iyice zayıfladı.” (s.38) Cümlesinde meslek adı ve saygı sözü küççik harfle yazılmıştır.

Doğrusu şöyle olmalıydı;

"İhtiyar: Her şeyi unutuyorum Doktor Bey, hafizam iyice zayıfladı."

“Gezici Kütüphane” adlı okuma parçasındaki örnekler;

“...ilk zamanlar kimse kitap almaz ama sonradan herkes bir merakla kitap almaya başlar." (s.51) Cümlesinde ayrılma tümleci eksikliği nedeniyle anlatım bozulmuştur.

Doğrusu şöyle olmalıydı;

“...Illk zamanlar kimse Mustafa Bey'den kitap almaz ama sonradan herkes bir merakla ondan kitap almaya başlar.”

“Ata Sporumuz Cirit” adlı okuma metnindeki örnekler;

"Cirit, Türklerin eski atlı spor oyunlarından biridir. At üzerindeki iki takımın yarışmacıları birbirlerine belli kurallara göre değnek atmalarıdır. Bu değneğin adı da cirittir.”(s.68) Cümlesinde ikinci cümlede nesne ve özne eksikliği nedeniyle anlatım bozulmuştur.

Doğrusu şöyle olmalıydı;

"Cirit, Türklerin eski atlı spor oyunlarından biridir. Oyun, at üzerindeki iki takımın yarışmacılarının birbirlerine belli kurallara göre değnek atmaları ile oynanır. Bu değneğin adı da cirittir.”

"Likya Yolu” adlı okuma parçasındaki örnekler;

"Likya Yolu" 3 bin ylllık eski bir ticaret yolu. Fethiye Ölüdeniz'den başlıyor, Antalya'da son buluyor. Yolun toplam uzunluğu 509 kilometre. Dünyanın en uzun yürüyüş rotalarından biri. Doğa ve yürüyüss tutkunları için inanılmaz güzellikte bir yol. Düz değil. İniş çıkışlarla dolu.

Geçen hafta arkadaşlarla bir araya geldik. Yolun Göynük-Karaöz arasındaki kısmını yürüdük. Tamamın yürümek çok zor.” (s.77) cümlelerinde nesne eksikliği, yüklem eksikliği ve özne eksikliğinden kaynaklanan anlatım bozuklukları oluşmuş̧tur.

Doğrusu şöyle olmalıydı;

"Likya Yolu” 3 bin ylllı eski bir ticaret yoludur. Yol, Fethiye Ölüdeniz'den başliyor, Antalya'da son buluyor. Yolun toplam uzunluğu 509 kilometredir. Likya Yolu, dünyanın en uzun yürüyüş rotalarından biridir. Doğa ve yürüyüş tutkunları için inanılmaz güzellikte bir yoldur ama o, düz değil, iniş çıkışlarla doludur.

Geçen hafta arkadaşlarla bir araya geldik. Yolun Göynük-Karaöz arasındaki kısmını yürüdük. Ama onun tamamını yürümek çok zor."

“Anneme Mektup” adlı metinde geçen örnekler;

“...Ben özellikle yatağımı çok sevdim, oldukça rahat. Kedili ve kuşlu desenleri var, sevimli ve komikler. Pencereden arka taraftaki ormanı görebiliyorum.” (s.114) cümlelerde özne ve nesne eksikliği nedeniyle anlatım bozulmuştur. 
An assessment on Turkish language books for teaching Turkish to foreigners taught at Jamia Millîa İslamia University, India / M. Şehitoğlu (pp. 106-127)

“...Ben özellikle yatağımı çok sevdim. O, oldukça rahat. Yatağımın kedili ve kuşlu desenleri var. Onlar sevimli ve komikler. Odamın penceresinden arka taraftaki ormanı görebiliyorum.”

“Kızarmış Ekmek Kokusu” adlı okuma parçasındaki örnekler;

“...Sedat'ın babası, onları çay bahçesine götürdü ve dondurma ısmarladı.” (s. 120). Cümlesinde yönelme tümleci eksikliği nedeniyle anlatım bozulmuştur.

Doğrusu şöyle olmalıydı;

“...Sedat’ın babası, onları çay bahçesine götürdü ve onlara dondurma ısmarladı.”

\section{B1 Türkçe Ders Kitabı:}

İlk ünitede yer alan “Genç İhtiyarlar” adlı okuma parçasında yer alan örnekler şöyledir:

"Kahramanmaraş'ta yaşayan 123 yaşındaki Mehmet Tatar, bir şeker firmasının reklam filminde oynadı. Oyunculuğunu herkes ayakta alkışladı.” (s.10). İkinci cümledeki tamlama eksikliği nedeniyle anlatım bozukluğu oluşmuştur.

\section{Doğrusu;}

"Kahramanmaraş'ta yaşayan 123 yaşındaki Mehmet Tatar, bir şeker firmasının reklam filminde oynadı. Onun oyunculuğunu herkes ayakta alkışladı.” şeklinde olmalıydı.

“...72 yaşında ama yarışmalarda birinciliği kimseye bırakmıyor. Odası madalya ve kupalarla dolu.” (s.10). Yine ikinci cümlede nesne eksikliğinden kaynaklanan anlatım bozukluğu oluşmuştur. Ayrıca bu cümlenin yer aldığı kısa metin parçasının bir sonraki -dır (pekiştirme) konusunun yer aldığı ünitedeki okuma metni bölümüne dahil edilmesi daha doğru olacaktır.

\section{Doğrusu;}

“...72 yaşında ama yarışmalarda birinciliği kimseye bırakmıyor. Onun odası madalya ve kupalarla dolu." Şeklinde olmalıydı.

“Ekonomist Serdar Şenol Değerlendiriyor” adlı okuma metninde ise, şu cümle yer almaktadır:

“Altın, bu yılın zirvesine çıktı.” (s.14). Cümlede vasıta grubu eksikliği nedeniyle anlatım bozukluğu oluşmuştur.

\section{Doğrusu;}

“Altın, dolar karşısında kazandığı değer ile bu yılın zirvesine çıktı.” şeklinde olmalıydı.

Aynı metinde bir diğer örnek şöyledir:

"Dolar, Amerika Bankalar Birliğinden gelen olumlu sinyallerle avro karşısında değer kazandı. Gün içinde küçük inişler çıkışlar yaşandı.” (s.14). İkinci cümledeki tamlama eksikliği nedeniyle anlatım bozukluğu oluşmuştur.

\section{Doğrusu;}

"Dolar, Amerika Bankalar Birliğinden gelen olumlu sinyallerle avro karşısında değer kazandı. Gün içinde doların değerinde küçük inişler çıkışlar yaşandı.” biçiminde olmalıydı. 
Yine, “İnceleyelim” adlı bölümdeki örnek cümle şöyledir:

“Fotoğraftaki kişi Oya'ya çok benziyor. Büyük bir ihtimalle annesidir.” (s.14). İkinci cümledeki tamlama eksikliği nedeniyle anlatım bozukluğu oluşmuştur.

Doğrusu;

"Fotoğraftaki kişi Oya’ya çok benziyor. Büyük bir ihtimalle Onun (Oya’nın) annesidir." şeklinde olmalıydı.

Aynı bölümde yer alan diğer örnek şöyledir:

"Saat sabahın altısı. Ayşe bu saatte hayatta kalkmaz. Uyuyordur." (s.14). Üçüncü cümledeki özne eksikliği nedeniyle anlatım bozukluğu oluşmuştur.

\section{Doğrusu;}

"Saat sabahın altısı. Ayșe bu saatte hayatta kalkmaz. O, uyuyordur." (s.14). Biçiminde olmalıydı.

“İletişim Araçları” adlı okuma metninde yer alan örnekler şöyledir:

"Radyo ve televizyon haber alma, eğitim ve eğlenceye yönelik araçlardır." (s.16). Cümlede tamlama eksikliği nedeniyle anlatım bozukluğu meydana gelmiştir.

Doğrusu;

"Radyo ve televizyon haber alma, eğitim ve eğlenceye yönelik iletişim araçlarıdır." biçiminde olmalıydı.

"Kitle iletişim araçlarının çoğalmasının başında ise, teknoloji gelmektedir." (s.16). Cümlede tamlama eksikliği ve sözcüklerin yanlış kullanımı nedeniyle anlatım bozukluğu oluşmuştur.

\section{Doğrusu;}

"Kitle iletişim araçlarının çoğalmasının ana nedeni ise, teknolojideki hızlı gelişmelerdir." şeklinde olmalıydı.

“-(I)yordu” biçim birimi ile ilgili “Cümle Tamamlama” bölümü içinde yer alan örnek ise şöyledir:

"Eskiden haftada bir kuaföre git......şimdi çok yorgunum.” (s.18). Cümlede "ama" bağlacı eksikliği ve ardından "gidemiyorum" eyleminin yazılmaması nedeniyle anlatım bozukluğu oluşmuştur.

\section{Doğrusu;}

"Eskiden haftada bir kuaföre git......ama şimdi çok yorgunum. Gidemiyorum.” şeklinde olmalıydı.

"Eskiden, çok eskiden” adlı okuma parçasında şu örnek yer almaktadır:

"Teknolojinin gelişmesi hayatımızı da kolaylaştırdı." (s.18).

Cümle, bir metnin giriş cümlesi olmaya uygun değildir. Çünkü cümlede dahi anlamındaki "-da” bağlacı fazla kullanılmıştır. Eğer bu şekilde kullanım olursa, hayat sözcüğünden önceki sözcük grubu eksik bırakılmış olur ve anlatım bozukluğu oluşur. 
An assessment on Turkish language books for teaching Turkish to foreigners taught at Jamia Millîa İslamia University, India / M. Şehitoğlu (pp. 106-127)

\section{Doğrusu;}

“Teknolojinin gelişmesi, hayatımızı kolaylaştırdı.” veya "Teknolojinin gelişmesi, eğitim, sağlık, hukuk gibi alanlar ile birlikte gündelik hayatımızı da kolaylaştırdı.” biçiminde olmalıydı.

“Peki geçmişte insanlar elektrik veya teknolojik aletler yokken nasıl yaşıyorlardı?” İnsanlar, gaz lambası veya mum kullanıyorlardı. Tabii elektrik yokken teknolojinin de bugünkü gibi olması mümkün değil.” (s.19). Bu metin bölümünde zaman tümleci eksikliği ve ek fiilin görülen geçmiş zaman eki eksikliği nedeniyle anlatım bozukluğu oluşmuştur. "elektrik veya teknolojik aletler" söz grubunda elektrik aletler tamlaması yanlıştır. Ayrıca, "Peki” sözcüğünden sonra da virgül eksikliği vardır.

\section{Doğrusu;}

“Peki, geçmişte insanlar elektrikli veya teknolojik aletler yokken nasıl yaşıyorlardı?” İnsanlar, geçmişte gaz lambası veya mum kullanıyorlardı. Tabii geçmişte elektrik yokken teknolojinin de bugünkü gibi olması mümkün değildi.” şeklinde olmalıydı.

Aynı metinde geçen diğer cümleler de şöyledir:

“Haberleşmek için mektup kullanıyorlardı.” Cümlede özne eksikliği nedeniyle anlatım bozukluğu vardir.

\section{Doğrusu;}

“İnsanlar, haberleşmek için mektup kullanıyorlardı."

biçiminde olmalıydl.

"Günler, haftalar, hatta aylar süren yolculuklara ya da kâğıt yokken insanların taşları kullanmasına ne diyorsunuz?" cümlesinde zaman tümleci eksikliği nedeniyle anlatım bozukluğu oluşmuştur. Ayrıca, "kâğıt" sözcüğünün doğru yazımı da "kâğıt" şeklinde olmalıydı.

\section{Doğrusu;}

“Geçmişte / Eskiden, günler, haftalar, hatta aylar süren yolculuklara ya da kâğıt yokken insanların taşları kullanmasına ne diyorsunuz?”

“Haberler” adlı okuma metninde geçen örnek cümleler ise şöyledir:

"Günümüz insanın iş dışında en fazla zaman ayırdığı etkinlikler arasında televizyon yer alır.” (s.20). Cümlesinde nesnenin eksik kullanımı dolayısıyla anlatım bozukluğu oluşmuştur.

\section{Doğrusu;}

"Günümüz insanın iş dışında en fazla zaman ayırdığı etkinlikler arasında televizyon izlemek yer alır."

biçiminde olmalıyd.

"Çağımızda, insan hayatını iletişim ve bilgilenme anlamında olumlu ya da olumsuz etkileyen önemli faktörlerden biridir."

Yine bu cümlede de nesne eksikliği nedeniyle anlatım bozulmuştur. 


\section{Doğrusu;}

"Çă̆ımızda, televizyon izlemek insan hayatını iletişim ve bilgilenme anlamında olumlu ya da olumsuz etkileyen önemli faktörlerden biridir." şeklinde olmallydı.

"Dünyanın herhangi bir yerindeki olaylardan haberdar olmamızı televizyon sağlar." Cümlenin devrik yapıda olması ve tekil-çoğul sözcüklerin eksik kullanılması nedeniyle anlatım bozulmuştur.

\section{Doğrusu;}

"Televizyon, dünyanın herhangi bir yerindeki olay veya olaylardan anında haberdar olmamızı sağlar.” biçiminde olmalıydı.

"Yetenek İşi” adlı metindeki örnek cümleler şöyledir:

"Bugünlerde annem biraz şikâyetçi, gürültüden uyuyamıyor ama gitar çalmakta üstüme yoktur." (s.21). Cümlesinde nesne ve kişi zamiri eksikliği nedeniyle anlatım bozulmuştur.

\section{Doğrusu;}

"Bugünlerde annem benden biraz şikâyetçi, gürültüden uyuyamıyor ama gitar çalmakta benim üstüme yoktur." şeklinde olmalıydı.

"Arkadaşımın sesi güzel bana şarkılarıyla eşlik eder." cümlesinde -dir bildirme kip eki ve kişi zamiri eksikliği nedeniyle anlatım bozulmuştur.

\section{Doğrusu;}

"Arkadaşımın sesi güzeldir. O, bana şarkılarıyla eşlik eder." biçiminde olmalıydı.

"Sosyal Medya" adlı okuma parçasında yer alan örnekler şöyledir:

"....Sivil toplum kuruluşları üyelerine ve gönüllülere bu sayfalar aracıllğıyla mesajlarını iletiyor." (s.23). Cümlesinde tamlama grubunun eksik kullanımı nedeniyle anlatım bozulmuştur.

\section{Doğrusu;}

“....Sivil toplum kuruluşları üyelerine ve gönüllülerine bu sayfalar aracılığıyla mesajlarını iletiyor.” şeklinde olmalıydı.

"Böylece sosyal paylaşım siteleri, büyük rol üstleniyor." cümlesinde nesne eksikliği nedeniyle anlatım bozulmuştur.

\section{Doğrusu;}

"Böylece sosyal paylaşım siteleri, iletişim konusunda büyük rol üstleniyor." biçiminde olmalıydı.

"Hayattan Kopuyoruz" adlı metinde ise, şu örnekler vardır:

“...Bu nedenle sosyal paylaşım siteleriyle iletișim kurmak yerine yüz yüze iletişim kurmak gerek.”

(s.23). Cümlede vasıta tümleci eksikliği nedeniyle anlatım bozukluğu oluşmuştur.

\section{Doğrusu;}

“...Bu nedenle insanlarla sosyal paylaşım siteleriyle iletişim kurmak yerine onlarla yüz yüze iletişim kurmak gerek." biçiminde olmalıyd.

“Tellal” adlı serbest okuma parçasında yer alan örnekler şöyledir: 
An assessment on Turkish language books for teaching Turkish to foreigners taught at Jamia Millîa İslamia University, India / M. Şehitoğlu (pp. 106-127)

“...Sonra Tellal, padişahın duyurularını, güzel ve gür sesleriyle halka iletir.” (s.24). Cümlesinde özne-nesne uyumsuzluğundan dolayı anlatım bozulmuştur.

Doğrusu;

“...Sonra Tellal, padişahın duyurularını, güzel ve gür sesiyle halka iletir.” biçiminde olmalıydı.

"Hat Sanatı" adlı okuma metninde yer alan örnekler şöyledir;

“...Matbaanın icadından önce çok önemli olan bu sanat sayesinde kutsal ve bilgi kitapları yazılmıştır.” (s.38). Cümlesinde tamlama eksikliği nedeniyle anlatım bozulmuştur.

Doğrusu şöyle olmalıydı;

“...Matbaanın icadından önce çok önemli olan bu sanat sayesinde kutsal kitaplar ve bilgi içerikli kitaplar yazılmıştır.”

“...Yazılar spontanedir ve sanatçı o an nasıl isterse o şekilde yapar.” cümlesinde yüklem eksikliği ve nesne eksikliği nedeniyle anlatım bozulmuştur. Ayrıca, spontane sözcüğü yerine Türkçe "kendiliğinden" sözcüğünün tercih edilmesi doğru olacaktır.

Doğrusu şöyle olmalıydı;

“...Yazılar kendiliğinden oluşur ve sanatçı onları o an nasıl isterse o şekilde yapar.”

“...Hattatlar kamışı yontarak şekil verirler.” cümlesinde yönelme tümleci eksikliği nedeniyle anlatım bozulmuştur.

Doğrusu şöyle olmalıydı;

“...Hattatlar kamışı yontarak ona şekil verirler.”

“Hayatımızdaki ‘Keşke’ler” adlı okuma metnindeki örnekler şöyledir;

“...Yaşlı insanlar gençlere göre daha dingin, farkında huzurludurlar.” (s.51). Cümlesinde tamlama eksikliği nedeniyle anlatım bozukluğu oluşmuştur.

Doğrusu şöyle olmalıydı;

“...Yaşlı insanlar gençlere göre daha dingin, hayatın farkında ve huzurludurlar.”

“...hatta aynı hataları yine ve tekrar yapmışlardır." cümlesinde ikileme yanlışı nedeniyle anlatım bozulmuştur.

Doğrusu şöyle olmalıydı;

“...hatta aynı hataları tekrar tekrar yapmışlardır.”

“Kitap Okumanın Faydaları” adlı okuma metninde yer alan örnekler şöyledir;

"...Kitaplar sayesinde bazen uçan bir halıya biner, bilmediğimiz diyarlara yolculuk ederiz; yeni arkadaşlıklar kurar, bazen hüzünlerimizi bazen neşemizi bu yeni arkadaşlarla paylaşırız." cümlelerinde zaman tümlecinin hatalı kullanılması ile ilgili anlatım bozukluğu oluşmuş̧tur." (s.62).

Doğrusu şöyle olmalıydı; 
“...Kitaplar sayesinde bazen uçan bir halıya biner, bilmediğimiz diyarlara yolculuk eder, yeni arkadaşlıklar kurarız; bazen de hüzünlerimizi ve neşemizi bu yeni arkadaşlarla paylaşırız.”

“Garanti Belgesi” adlı okuma metnindeki örnek şöyledir;

“...Kemal, çantanın içinden tapu belgesi çıkarır ve annesine verir.” (s.82). Cümlesinde nesne eksikliği nedeniyle anlatım bozulmuştur.

Doğrusu şöyle olmalıydı;

“...Kemal, çantanın içinden tapu belgesi çlkarır ve onu annesine verir.”

"Yağmur Adam” adlı okuma metnindeki örnek şöyledir;

“...Babası öldükten sonra 3 milyon dolar miras kalır.” (s.98). Cümlesinde yönelme tümleci eksikliği nedeniyle anlatım bozulmuştur.

Doğrusu şöyle olmalıydı;

“...Babası öldükten sonra ona 3 milyon dolar miras kahır.”

“Nasıl Yardım Ederiz” adlı okuma parçasındaki örnek şöyledir;

"Zaman zaman engelli bireylerle karşılaşırı. Bizden çeşitli konularda yardım isterler." (s.104). Cümlesinde ikinci cümledeki özne eksikliği nedeniyle anlatım bozulmuştur.

Doğrusu şöyle olmalıydı;

"Zaman zaman engelli bireylerle karşılaşırız. Onlar bizden çeşitli konularda yardım isterler."

\section{B2 Türkçe ders kitabı}

"Ylllar Sonra" adlı okuma metninde yer alan örnekler şöyledir:

"Polat: ...Liseden sonra mimarlık fakültesine devam ettim."

“Ertan: Ben de Liseden sonra işletme bölümüne devam ettim.” (s.10). Cümlelerinde büyük harflerin kullanımı ile ilgili yanlışılı vardır.

Doğrusu;

"Polat: ...Liseden sonra Mimarlık Fakültesine devam ettim."

“Ertan: Ben de Liseden sonra İşletme Bölümüne devam ettim.” şeklinde olmalıydı.

"Polat: ...Ziraat fakültesini tamamlayacak ve kendine ait büyük bir çiftlik kuracaktın."

"Ertan: ...Belki ziraat fakültesine gitseydim...”

"Ertan: ... Hayat şartları beni iktisat fakültesine yönlendirdi." cümlelerinde büyük harflerin kullanımı ile ilgili yanlışlar mevcuttur.

\section{Doğrusu:}

"Polat: ...Ziraat Fakültesini tamamlayacak ve kendine ait büyük bir çiftlik kuracaktı.."

"Ertan: ...Belki Ziraat Fakültesine gitseydim..." 
An assessment on Turkish language books for teaching Turkish to foreigners taught at Jamia Millîa İslamia University, India / M. Şehitoğlu (pp. 106-127)

“Ertan: ... Hayat şartları beni İktisat Fakültesine yönlendirdi.” şeklinde olmalıydı.

"Erasmus” adlı okuma parçasında geçen örnekler şöyledir:

"Programın amacı; Avrupa'da yüksek öğretimin kalitesini artırmak ve Avrupa boyutunu güçlendirmektir.” (s. 24). Cümlesinde boyut sözcüğünün anlam değeri cümlenin anlatımını bozmuştur. Ayrıca, “yüksek öğretim” sözcüğünün doğru yazımı “yükseköğretim” şeklinde olmaliydı."

Doğrusu:

"Programın amacı; Avrupa'da yükseköğretimin kalitesini artırmak ve onun Avrupa'daki etkinliğini güçlendirmektir." biçiminde olmalıydı.

"Daha kaliteli yükseköğretim sunan Avrupa'da mezunlar daha donanımlı, iş dünyasının beklentilerine daha fazla cevap veren bireyler olacaklardır." cümlede tamlama eksikliği ve özne eksikliği nedeniyle anlatım bozulmuştur.

\section{Doğrusu;}

“Avrupa'nın yükseköğretim kurumlarında daha kaliteli eğitim ve öğretim alan mezunlar daha donanımlı olacaklar ve onlar iş dünyasının beklentilerine daha fazla cevap veren bireyler olacaklardır.” şeklinde olmalıydı.

“Sanata Adanmış Bir Ömür” adı metinde geçen örnekler şöyledir:

“...Padişah onu karşısında görünce yanında yer göstererek oturmasını istedi. İkramlarda bulundu ve sohbet etti.” (s. 113). Cümlesinde yönelme tümleci ve bağlama grubu eksikliği nedeniyle anlatım bozulmuştur.

Doğrusu şöyle olmalıydı:

“...Padişah onu karşısında görünce yanında yer göstererek oturmasını istedi. Ona ikramlarda bulundu ve onunla sohbet etti."

“40 Yıl 2 Dakika” adlı okuma parçasında geçen örnekler şöyledir:

“...Picasso’nun önünde minnetle eğilir ve şükranlarını sunar.” (s. 115) Cümlesinde yönelme tümleci eksikliği nedeniyle anlatım bozulmuştur.

Doğrusu şöyle olmalıydı:

“...Picasso’nun önünde minnetle eğilir ve ona şükranlarını sunar.”

\section{Tartışma}

Hindistan Jamia Millîa İslamia Üniversitesi Türk Dili ve Edebiyatı Bölümünde yabancı dil olarak öğretilen Türkçenin dil bilgisi öğretiminde kitapların metin içeriğinde birçok eksiklik ve yanlışlık tespit edilmiştir. Alanyazında Türkiye'de ve yurt dışında bu konuyla ilgili yapılan araştırmalarda yabancılara Türkçe öğretiminde en çok karşılaşılan güçlüğün dil bilgisi konularında görüldüğü araştırmacılar tarafından dile getirilmiştir.

Türkiye'de bu konuyla ilgili yapılan araştırmalarda dil bilgisi öğretiminde eklerin kullanımı ve özellikle de ad durum eklerinin kullanımında zorluk yaşandığı öğrenenler tarafından ifade edilmiştir (Candaş 
Karababa, 2009). Ayrıca yine Türkiye'de bu konuda yapılan araştırmalarda dil bilgisi öğretiminde tamlama eklerinin öğrenilmesinde öğrenenlerin zorluk çektiği de tespit edilmiştir (Bakır, Biçer \& Çoban, 2014; Alyılmaz, Biçer \& Çoban, 2015).

Yurt dışında yapılan araştırmalarda yine aynı sorunun dile getirildiği görülmekte öğrenenlerin kültür farklılığı ve coğrafya farklılığı olsa da dil bilgisinin öğrenilmesinde zorluklar yaşadıklarını ifade ettikleri görülmüştür. İran'da Türkçeyi yabancı dil olarak öğrenen öğrenciler üzerinde yazma eğitimi bağlamında yapılan araştırmada da yazma becerisinde karşılaşılan zorluların büyük bölümünün dil bilgisi konularının eksik veya yanlış anlaşılmasından oluştuğu görülmüştür. Bu bağlamda ses bilgisi, biçim bilgisi ve eklerin kullanımı ile ilgili kategorik bir inceleme de yapılmıştır (Boylu, 2014).

Yine Türkiye'deki Türkçe eğitimi ile ilgili genel sorunların ele alındığı bir diğer çalışmada da hem ana dil hem de yabancı dil olarak Türkçenin öğretilmesinde dil bilgisi konularındaki sorunlar temel olarak aynı düzeyde görülmüştür. Okutulan Türk dil bilgisi ders kitaplarında Türkçenin derin yapısına ait özelliklerin göz ardı edildiği, anlamlı ve görevli ögelerin işlevsel boyutunun yansıtılmadığı, bilgilerin sadece ezber niteliğinde ve kolayca unutulacak şekilde sunulduğu, ilgili kitaplarda ortak bir terminoloji kullanılmadığı dile getirilmiştir (Alyılmaz, 2010, s. 738-739).

\section{Sonuç}

Araştırmada, ders materyalleri ve ders kitaplarının içeriğine yönelik yapılan tespitler dışında kalan Jamia Millîa İslamia Üniversitesinin yönetim biçimi ve fizikî koşulları ile ilgili tespitlerin Türkçenin öğretimini dolaylı da olsa etkilediği düşünülmekte ve bu sorunların en kısa sürede ilgili makamlarca çözüleceğine inanılmaktadır.

Okutulan Türkçe ders kitaplarının metin boyutunda tespit edilen anlatım bozukluğu ve dil yanlışlarına yönelik eksikliklerde seviyelere göre değişik türde yanlışlıklar ve eksiklikler tespit edilmiştir. Tespitlerden hareketle;

A1 seviyesinde okutulan Türkçe ders kitabında okuma metinleri ve parçalarında herhangi bir yanlışlık ve eksikliğe rastlanmamıştır.

A2 seviyesinde okutulan Türkçe ders kitabındaki okuma metinleri ve parçalarında anlatım bozukluğuna neden olan toplam 18 yanlışlı ve eksiklik tespit edilmiştir. Anlatım bozukluğu yönünden 5 kez özne eksikliğinden kaynaklanan anlatım bozukluğu oluşmuş ve bu eksiklik toplamda en fazla görülen eksiklik olmuştur.

B1 Türkçe ders kitabında toplam 33 yanlışlık ve eksiklik tespit edilmiştir. Bu yanlışlık ve eksiklikler 9 kez görülen tamlama eksikliğinden kaynaklanmıştır. Nesne eksikliğinden kaynaklanan anlatım bozukluğunun 7 kez gerçekleştiği tespit edilmiştir.

B2 Türkçe ders kitabında ise, toplam 5 yanlışlık ve eksiklik tespit edilmiştir. En fazla anlatım bozukluğu ise, 2 kez gerçekleşen yönelme tümleci eksikliğinden kaynaklandığı tespit edilmiștir. Bu veriler ışığında özellikle B2 seviyesindeki Türkçe ders kitabının okuma metinlerinin daha titiz ve daha dikkatli hazırlanması gerektiği görülmektedir. Ayrıca, okuma metinlerinde yapılan bu türden yanlışlıkların dil bilgisi öğretimini ve diğer dinleme, konuşma ve yazma becerilerini de etkilediği görev yapılan süre boyunca yapılan ölçme ve değerlendirme sınavlarında ve ödev çalışmalarında tespit edilmiştir.

Çalışmanın bu veriler ışığında, okutulan Türkçe ders kitaplarının Türkçe öğretiminde daha etkin ve işlevsel kullanılmasına katkı sunacağı düşünülmektedir.

\section{Öneriler}


An assessment on Turkish language books for teaching Turkish to foreigners taught at Jamia Millîa İslamia University, India / M. Şehitoğlu (pp. 106-127)

Ayrıca Türkçe ders kitaplarındaki okuma metinlerinde yazım yanlışlıkları, dil yanlışlıkları da mevcuttur. Özellikle büyük harflerin doğru kullanımı ilgili yanlışlıklar dikkat çekicidir. Metinler hazırlanırken sözcüklerin doğru yazımına titizlikle dikkat edilmesi önerilmektedir:

\section{A2 düzeyi Türkçe ders kitabı}

“...1999 yılı mayıs ayında ilk albümünü hazırladı.” (s.14).

Doğrusu;

“...1999 yılının Mayıs ayında ilk albümünü hazırladı.” biçiminde olmalıydı.

“İhtiyar: Her şeyi unutuyorum doktor bey, hafızam iyice zayıfladı.” (s.38) cümlesinde meslek adı ve saygı sözü küçük harfle yazılmıştır.

Doğrusu şöyle olmalıydı;

“İhtiyar: Her şeyi unutuyorum Doktor Bey, hafızam iyice zayıfladı.”

\section{B2 düzeyi Türkçe ders kitabı}

"Polat: ...Liseden sonra mimarlık fakültesine devam ettim."

"Ertan: Ben de Liseden sonra işletme bölümüne devam ettim.” (s.10).

Doğrusu;

"Polat: ...Liseden sonra Mimarlık Fakültesine devam ettim.”

“Ertan: Ben de Liseden sonra İşletme Bölümüne devam ettim.” şeklinde olmalıydı.

"Polat: ...Ziraat fakültesini tamamlayacak ve kendine ait büyük bir çiftlik kuracaktın."

"Ertan: ...Belki ziraat fakültesine gitseydim..."

"Ertan: ... Hayat şartları beni iktisat fakültesine yönlendirdi.”

Doğrusu:

"Polat: ...Ziraat Fakültesini tamamlayacak ve kendine ait büyük bir çiftlik kuracaktın.”

"Ertan: ...Belki Ziraat Fakültesine gitseydim..."

“Ertan: ... Hayat şartları beni İktisat Fakültesine yönlendirdi.” şeklinde olmalıydı.

\section{Kaynakça}

Alyılmaz, C. (2010). Türkçe öğretiminin sorunları. Turkish Studies, International Periodical for Languages, Literature and History of Turkish or Turkic, Vol. 5/3 Summer, 728-79.

Alyılmaz, S., Biçer, N., \& Çoban, İ., (2015). Atatürk Üniversitesinde öğrenim gören Kırgız öğrencilerin Türkçe ve Türkiye’ye yönelik görüşleri. Uluslararası Türkçe Edebiyat Kültür Eğitim Dergisi, 4 (1), 328-338.

Azizoğlu, İ. N. \& Uğur, F. (2015). Türkçenin yabancı dil olarak öğretiminde kullanılan ders kitaplarının sözcük öğretimi açısından değerlendirilmesi. Ana Dili Ĕ̆itimi Dergisi, 4 (1), 151-166. 
Başar, U. (2016). Yunus Emre Enstitüsü yedi iklim Türkçe setinin (Temel Seviye: A1, A2) yapılandırmacılık bağlamında değerlendirilmesi. İstanbul Aydın Üniversitesi Aydın TÖMER Dil Dergisi, 1 (2), 55-77.

Biçer, N. \& Çoban,İ. \& Bakır, S. (2014). Türkçe öğrenen yabancı öğrencilerin karşılaştığı sorunlar. Atatürk Üniversitesi Örneği. Uluslararası Sosyal Araştırmalar Dergisi, 7 (29), 125-135.

Bilkan, F. A. (2011). Halide Edip Adıvar’ın Hindistan'daki konferansları. bilig dergisi, Kış, 56, 33-44.

Boylu, E. (2014). Yabancı dil olarak Türkçe öğrenen temel seviyedeki İranlı öğrencilerin yazma problemleri. Journal of World of Turks, Vol, 6 (2), 335-49.

Dilidüzgün, Ş. \& Yllmaz, Ö. (2019). Yabancı dil olarak Türkçe öğretiminde Metin odaklı dil bilgisi öğretimi üzerine öğrenci görüşleri. Ana Dili Eğitimi Dergisi, 7(1), 217-234.

Güneş, F. (2009). Hızlı okuma ve anlamı yapılandırma Ankara: Nobel.

Güneş, F. (2011). Dil öğretim yaklaşımları ve Türkçe öğretimindeki uygulamalar. Mustafa Kemal Üniversitesi Sosyal Bilimler Enstitüsü Dergisi, 8 (5), 123-148.

Güneş, F. (2013). Türkçe öğretimi yaklaşımlar ve modeller Ankara: Pegem Akademi.

Güneş, F. (2013). Dil bilgisi öğretiminde yeni yaklaşımlar. Dil ve Edebiyat Eğitimi Dergisi, 2 (7), 7192.

Karababa Candaş, C. Z. (2009). Yabancı dil olarak Türkçenin öğretimi ve karşılaşılan sorunlar. Ankara Üniversitesi Ĕ̆itim Bilimleri Fakültesi Dergisi, 42 (2), 265-277.

TDV İslam Ansiklopedisi (2016). Ek-1.

Yıldırım, A. \& Şimşek, H. (2008). Sosyal bilimlerde nitel araştırma yöntemleri Ankara: Seçkin.

Yıldırım, A. \& Şimşek, H. (2012). Sosyal bilimlerde nitel araştırma yöntemleri, Ankara: Seçkin.

Yıldırım, A. \& Şimşek, H. (2012). Sosyal bilimlerde nitel araştırma yöntemleri Ankara: Seçkin. 